EXPERIMENTAL STUDY

\title{
Inhibitory effect of ghrelin on insulin and pancreatic somatostatin secretion
}

\author{
E M Egido, J Rodríguez-Gallardo, R A Silvestre and J Marco \\ Clínica Puerta de Hierro y Departamento de Fisiologia, Universidad Autónoma de Madrid, Madrid, Spain
}

(Correspondence should be addressed to J Marco,Clínica Puerta de Hierro, Universidad Autónoma de Madrid, San Martín de Porres 4, 28035 Madrid, Spain; Email: jmarco@hpth.insalud.es)

\begin{abstract}
Objective: Ghrelin is a 28 amino acid residue peptide identified in both human and rat stomach and which acts as an endogenous ligand for the GH secretagogue receptor (GHS-R) and stimulates GH release. GHS-Rs are expressed in a number of tissues, including the pancreas, and ghrelin-like immunoreactivity is present in peripheral plasma, where its levels increase during fasting and decrease after food intake. The relationship between nutritional status and circulating ghrelin concentrations prompted us to investigate the effect of this peptide on pancreatic hormone secretion.

Methods: The study was performed in the isolated rat pancreas perfused in situ. Insulin, glucagon and somatostatin were measured by radioimmunoassay.

Results: Addition of $10 \mathrm{nM}$ ghrelin to the perfusate significantly reduced the insulin response to the secretagogues glucose, arginine and carbachol, which act on the B-cell via different mechanisms, as well as the somatostatin response to arginine. Ghrelin was without effect on the glucagon output induced by this amino acid. At a lower concentration $(2 \mathrm{nM})$ ghrelin was also found to inhibit glucose-induced insulin release.

Conclusion: These findings support the proposal that the inhibitory effect of ghrelin on insulin release constitutes a tonic regulation of the B-cell, contributing to restrain its secretory activity in the state of food deprivation. On the other hand, the inhibition of pancreatic somatostatin release by ghrelin suggests a blocking effect of this hormone on the widely distributed D-cell population.
\end{abstract}

European Journal of Endocrinology 146 241-244

\section{Introduction}

Ghrelin is a novel 28 amino acid residue peptide first identified in both human and rat stomach and which acts as an endogenous ligand for the growth hormone (GH) secretagogue receptor (GHS-R) and stimulates GH release $(1,2)$. GHS-Rs are expressed in both hypothalamus and pituitary $(1,3-5)$ as well as in the stomach $(1,4)$, intestine (1) and pancreas (1).

In the stomach, ghrelin is synthesized from preproghrelin in the A-like cells of the oxyntic mucosa (6), and ghrelin-like immunoreactivity has also been found in the small intestine, colon, rectum and pancreas $(1,6)$. Ghrelin-like immunoreactivity is present in human plasma, where its levels are reduced by food intake (7). Likewise, in the rat, circulating ghrelin increases during prolonged fasting and decreases upon re-feeding $(6,8,9)$. Furthermore, it has recently been reported that circulating ghrelin levels are decreased in human obesity (10). These observations suggest a role for ghrelin in fuel homeostasis.
The present work was undertaken to examine the effects of rat ghrelin on insulin, glucagon and somatostatin secretion in the perfused rat pancreas.

\section{Materials and methods}

Male Wistar rats from our inbred colony (7-8 weeks of age, 200-225 g body weight) fed ad libitum were used as donors. Animals were maintained in accordance with the guidelines established by the European Union (86/609). After anesthesia of the rat with pentobarbital sodium $(50 \mathrm{mg} / \mathrm{kg}$, i.p.), the pancreas was dissected and perfused in situ according to the procedure of Leclercq-Meyer et al. (11) as adapted in our laboratory (12). Rat ghrelin (n-octanoylated), purchased from Peptides International (Louisville, KY, USA), was dissolved in $0.9 \% \mathrm{NaCl}$ containing $0.1 \%$ bovine albumin (Cohn fraction V). This solution was prepared daily, immediately before experiments. When added to the perfusate, the final concentration was 2 or $10 \mathrm{nM}$ ghrelin. Insulin secretion was stimulated by increasing 
the perfusate glucose concentration (from 5.5 to $9 \mathrm{mM}$ ), and by infusion of $10 \mathrm{mM}$ L-arginine hydrochloride (Sigma, St Louis, MO, USA) or $1 \mu \mathrm{M}$ carbachol (Sigma). Additions to the perfusate were performed as described in the corresponding figures. Glucagon and somatostatin were measured in some experiments. Insulin $(13,14)$, glucagon (15) and somatostatin (16) were analyzed by radioimmunoassay. Anti-pig insulin serum (I8510; Sigma) and rat insulin standards (Novo Nordisk, Bagsvaerd, Denmark) were employed. Anti-glucagon serum (04A) and anti-somatostatin serum $(80 \mathrm{C})$ were kindly donated by R H Unger (University of Texas, Health Sciences Center, Dallas, TX, USA). Ghrelin did not cross-react with any of the antisera employed. The interassay variations were 5.6\%, $7.8 \%$ and $6.4 \%$ for insulin, glucagon and somatostatin respectively, and the intra-assay variations were $4 \%$, $5.6 \%$ and $4.6 \%$ respectively. Experiments were randomized and all samples for each series of perfusions were analyzed within the same assay. Results are expressed as the means \pm S.E.M. Hormone response was calculated as the integrated area of the curve above the mean preinfusion level (average of all the baseline levels for each perfusion) employing the trapezoidal method. Statistical calculations were performed by analysis of variance and by Student's $t$-test for unpaired samples.

\section{Results}

As shown in Fig. 1, addition of $10 \mathrm{nM}$ ghrelin to the perfusate did not significantly modify basal insulin release $\left(\mathrm{F}_{10,50}=0.54\right.$; not significant (n.s.)) but markedly inhibited the insulin response to increasing glucose concentrations (from 5.5 to $9 \mathrm{mM}$ ) (incremental area:

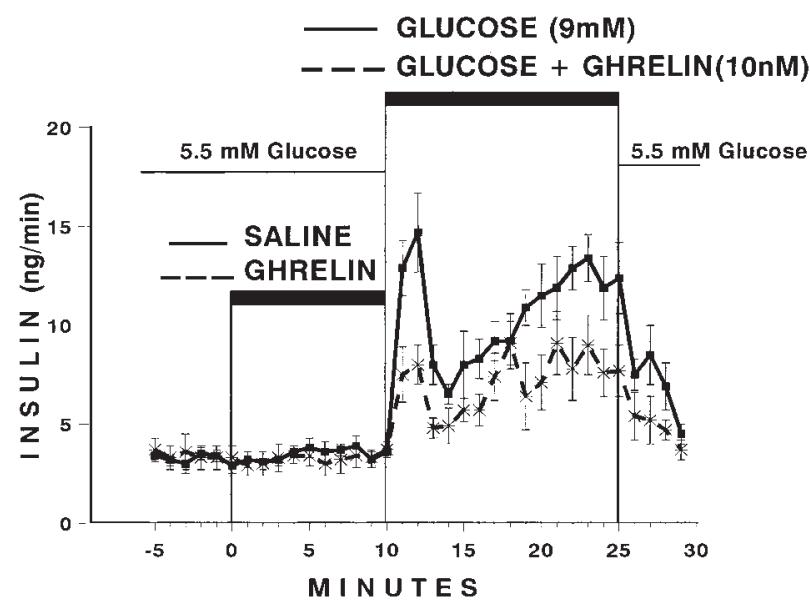

Figure 1 Effect of $10 \mathrm{nM}$ rat ghrelin on the insulin response to increasing glucose concentration (from 5.5 to $9 \mathrm{mM}$ ) in the perfused rat pancreas. The solid line corresponds to control experiments: from 10 to $25 \mathrm{~min}, 9 \mathrm{mM}$ glucose infusion $(n=9)$. The broken line corresponds to ghrelin experiments: from 0 to $10 \mathrm{~min}$, ghrelin infusion at $5.5 \mathrm{mM}$ glucose; from 10 to $25 \mathrm{~min}, 9 \mathrm{mM}$ glucose + ghrelin infusion $(n=6)$. Values are means \pm S.E.M.

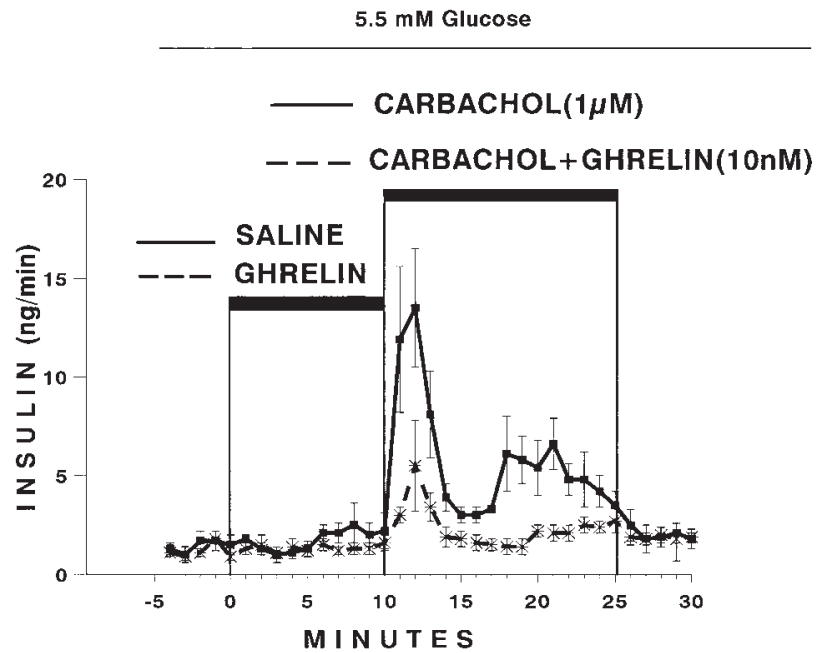

Figure 2 Effect of $10 \mathrm{nM}$ rat ghrelin on the insulin response to $1 \mu \mathrm{M}$ carbachol in the perfused rat pancreas. The solid line corresponds to control experiments: from 10 to $25 \mathrm{~min}, 1 \mu \mathrm{M}$ carbachol infusion $(n=5)$. The broken line corresponds to ghrelin experiments: from 0 to $10 \mathrm{~min}$, ghrelin infusion at $5.5 \mathrm{mM}$ glucose; from 10 to $25 \mathrm{~min}, 1 \mu \mathrm{M}$ carbachol+ghrelin infusion $(n=6)$. Values are means \pm S.E.M.

$55 \pm 17 \mathrm{ng} / 15 \mathrm{~min}$ vs $107 \pm 13 \mathrm{ng} / 15 \mathrm{~min}$ in control experiments; $P<0.05)$.

Figure 2 shows that ghrelin $(10 \mathrm{nM})$ also blocked the insulin release elicited by $1 \mu \mathrm{M}$ carbachol (incremental area: $18 \pm 5.6 \mathrm{ng} / 15 \mathrm{~min}$ vs $65 \pm 11 \mathrm{ng} / 15 \mathrm{~min}$ in control experiments; $P<0.01)$.

Figure 3 shows the effect of $10 \mathrm{nM}$ ghrelin on the insulin, glucagon and somatostatin responses to $5 \mathrm{mM}$ arginine. As depicted in Fig. 3A, ghrelin significantly reduced the second phase of the arginineinduced insulin release (incremental area: $78 \pm$ $16 \mathrm{ng} / 10 \mathrm{~min}$ vs $176 \pm 33 \mathrm{ng} / 10 \mathrm{~min}$ in control experiments; $P<0.05)$. As demonstrated in Fig. 3B, neither basal glucagon output $\left(\mathrm{F}_{10,80}=1.24\right.$; n.s. $)$ nor the glucagon response to arginine (incremental area: $14.1 \pm 3.1 \mathrm{ng} / 15 \mathrm{~min}$ vs $14.7 \pm 4.2 \mathrm{ng} / 15 \mathrm{~min}$ in control experiments; $P=0.91$ ) were significantly modified by ghrelin. Figure $3 \mathrm{C}$ shows that $10 \mathrm{nM}$ ghrelin significantly reduced the somatostatin response to arginine (incremental area: $627 \pm 327 \mathrm{pg} / 15 \mathrm{~min}$ vs $1530 \pm$ $225 \mathrm{pg} / 15 \mathrm{~min}$ in control perfusions; $P<0.05)$. Basal somatostatin release was not affected by ghrelin $\left(\mathrm{F}_{10,80}=0.83\right.$; n.s. $)$.

Finally, Fig. 4 shows that a lower ghrelin concentration $(2 \mathrm{nM})$ significantly reduced glucose-induced insulin release (incremental area: $49 \pm 10 \mathrm{ng} / 15 \mathrm{~min}$ vs $104 \pm 12 \mathrm{ng} / 15 \mathrm{~min}$ in control experiments; $P<0.025)$.

\section{Discussion}

The foregoing results first demonstrate that, in the isolated rat pancreas, infusion of homologous ghrelin 


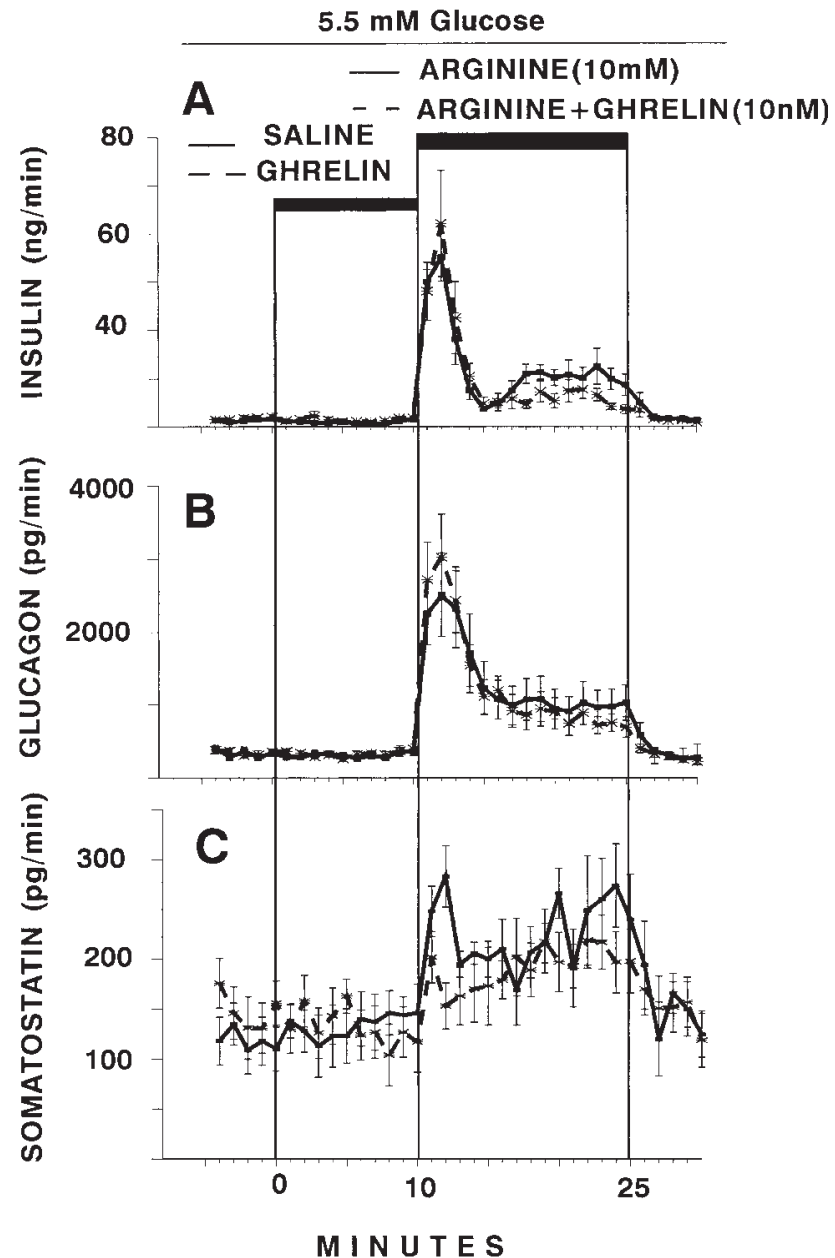

Figure 3 Effect of $10 \mathrm{nM}$ rat ghrelin on the insulin (A), glucagon (B) and somatostatin (C) responses to $10 \mathrm{mM}$ arginine in the perfused rat pancreas. The solid line corresponds to control experiments: from 10 to $25 \mathrm{~min}, 10 \mathrm{mM}$ arginine infusion (A, $n=5$; $\mathrm{B}, n=10 ; \mathrm{C}, n=8$ ). The broken line corresponds to ghrelin experiments: from 0 to $10 \mathrm{~min}$, ghrelin infusion at $5.5 \mathrm{mM}$ glucose; from 10 to $25 \mathrm{~min}, 10 \mathrm{mM}$ arginine + ghrelin infusion $(\mathrm{A}, n=5$; $\mathrm{B}, n=9 ; \mathrm{C}, n=9)$. Values are means \pm S.E.M.

directly inhibits the insulin responses to glucose, arginine and carbachol, as well as the release of somatostatin evoked by arginine. Ghrelin was without effect on the glucagon output induced by this amino acid.

The perfused rat pancreas, while a suitable model to characterize the pancreatic hormone secretory pattern elicited by ghrelin, does not allow direct investigation of the detailed mechanism of action of this peptide. The inhibitory effect of ghrelin on insulin release elicited by secretagogues acting on the B-cell via different pathways may be due to a multifarious influence of this peptide on the B-cell stimulus-secretion coupling mechanism and/or a disturbing effect on a distal, crucial step in the insulin-releasing process, e.g. by affecting exocytosis. Given that ghrelin inhibits the insulin output evoked by carbachol, a substance acting on

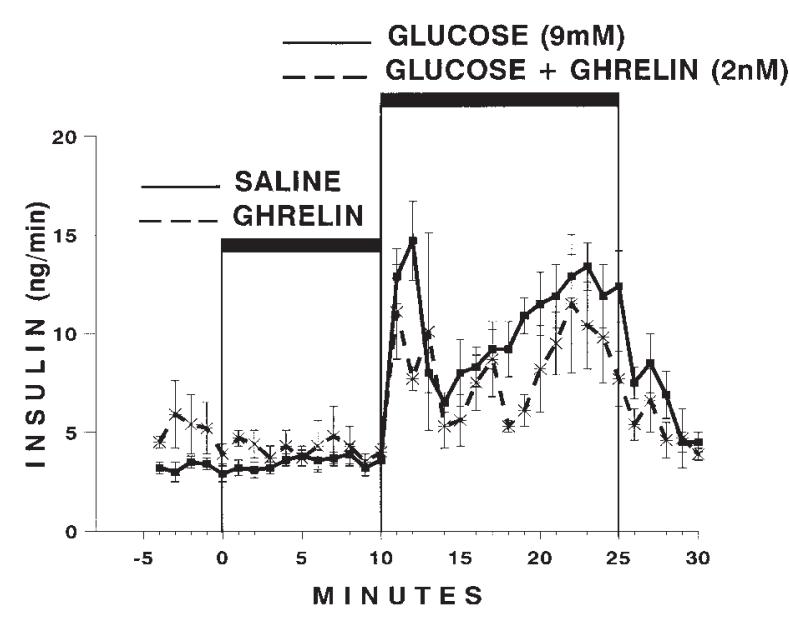

Figure 4 Effect of $2 \mathrm{nM}$ rat ghrelin on the insulin response to increasing glucose concentration (from 5.5 to $9 \mathrm{mM}$ ) in the perfused rat pancreas. The solid line corresponds to control experiments: from 10 to $25 \mathrm{~min}, 9 \mathrm{mM}$ glucose infusion $(n=9)$. The broken line corresponds to ghrelin experiments: from 0 to $10 \mathrm{~min}$, $2 \mathrm{nM}$ ghrelin infusion at $5.5 \mathrm{mM}$ glucose; from 10 to $25 \mathrm{~min}, 9 \mathrm{mM}$ glucose $+2 \mathrm{nM}$ ghrelin infusion $(n=6)$. Values are means \pm S.E.M.

the B-cell by receptor-mediated activation of phospholipase $\mathrm{C}$ and stimulation of inositol phospholipid turnover (17), it can be inferred that this pathway, which plays an important role in B-cell secretion, is interfered with by ghrelin.

In apparent discrepancy with the anticholinergic effect of ghrelin we observed, Masuda et al. (18) have demonstrated that ghrelin stimulates gastric acid secretion as well as gastric acid motility by activating the vagal system. It should be stressed that, in our isolated pancreas model, islet cells are disconnected from the autonomous nervous system and, thus, the effect of ghrelin represents a direct influence on these cells.

Somatostatin has been shown to be an effective inhibitor of both insulin and glucagon secretion in a number of experimental conditions (19); thus, under ghrelin-induced suppression of somatostatin output, an increase in the secretory responses of these two hormones could be expected. However, the paracrine role of the D-cell in the control of B-cell and A-cell secretion is, in our opinion, not clearly elucidated. In fact, previous work from our laboratory, performed in the perfused rat pancreas, showed that in somatostatindepleted pancreases, the absence of somatostatin release did not alter the normal insulin secretory pattern induced by various secretagogues (12).

Besides the inhibitory effect of ghrelin on pancreatic somatostatin release here described, Tolle et al. (20) demonstrated recently that addition of rat ghrelin to a preparation of perifused rat hypothalamic fragments significantly inhibited release of somatostatin induced by $\mathrm{K}^{+}$depolarization, while basal somatostatin release was not modified under the same conditions. The latter finding is in accordance with the failure of 
ghrelin to alter either unstimulated insulin or unstimulated somatostatin output. Taken together, these observations suggest that blockade of somatostatin secretion by ghrelin might affect the D-cells widely distributed throughout tissues, an effect worthy of further investigation.

Information on circulating levels of ghrelin is scarce. In humans, fasting plasma levels range from 0.1 to $0.25 \mathrm{nM}(1,7,10)$ and, in fasted rats, values between 0.2 and $1 \mathrm{nM}$ have been reported $(4,6,9,21)$. Moreover, two major molecular forms of ghrelin, octanoylated and des-octanoylated, have been found in peripheral plasma, the latter of which does not activate GHS-R-expressing cells (21). Thus the octanoylated ghrelin concentrations we tested $(2 \mathrm{nM}$ and $10 \mathrm{nM})$ should be considered pharmacological. However, ghrelin-like immunoreactivity has been found in the pancreas $(1,8,21)$ and, in addition to the ghrelin reaching the B-cell through the systemic circulation, the local production of the hormone would augment its intra-islet concentration.

At present, conjecture about the implication of ghrelin in the regulation of insulin secretion would be highly speculative. Given that plasma ghrelin levels augment during fasting $(6,8,9)$, it could be thought that the inhibitory effect of ghrelin on insulin release constitutes a tonic regulation of the B-cell, contributing to restrain its secretory activity in the state of food deprivation. Conversely, the reduction of circulating levels of ghrelin observed in human obesity (10) might contribute to the hyperinsulinemia characteristic of adiposity.

\section{Acknowledgements}

This work has been supported by grants from the Fondo de Investigación Sanitaria (FIS), Ministerio de Sanidad y Consumo (00/121) and from the Comunidad Autónoma de Madrid (8.6/0005/98), Spain. J R-G is a postdoctoral research fellow from the Comunidad Autónoma de Madrid, and E M E is a predoctoral fellow from the FIS. We thank M Messman for her secretarial help. The expert technical assistance of $E$ Gutiérrez and P García is gratefully acknowledged.

\section{References}

1 Kojima M, Hosoda H, Date Y, Nakazato M, Matsuo H \& Kangawa $\mathrm{K}$. Ghrelin is a growth-hormone-releasing acylated peptide from stomach. Nature $1999 \mathbf{4 0 2}$ 656-660.

2 Dieguez C \& Casanueva FF. Ghrelin: a step forward in the understanding of somatotroph cell function and growth regulation. European Journal of Endocrinology 2000142 413-417.

3 McKee KK, Palyha OC, Feighner SD, Hreniuk DL, Tan CP, Phillips MS et al. Molecular analysis of rat pituitary and hypothalamic growth hormone secretagogue receptors. Molecular Endocrinology $199711415-423$.
4 Shuto Y, Shibasaki T, Wada K, Parhar I, Kamegai J, Sugihara H et al. Generation of polyclonal antiserum against the growth hormone secretagogue receptor (GHS-R): evidence that the GHS-R exists in the hypothalamus, pituitary and stomach of rats. Life Sciences $200168991-996$.

5 Papotti M, Ghe C, Cassoni P, Catapano F, Deghenghi R, Ghigo E et al. Growth hormone secretagogue binding sites in peripheral human tissues. Journal of Clinical Endocrinology and Metabolism 200085 3803-3807.

6 Dornonville de la Cour C, Björkqvist M, Sandvik AK, Bakke I, Zhao CM, Chen D et al. A-like cells in the rat stomach contain ghrelin and do not operate under gastrin control. Regulatory Peptides 200199 141-150.

7 Tschöp M, Wawarta R, Riepl RL, Friedrich S, Bidlingmaier M, Landgraf $\mathrm{R}$ et al. Postprandial decrease of circulating human ghrelin levels. Journal of Endocrinological Investigation $20012 \mathbf{2 4}$ RC19-RC21.

8 Tschöp M, Smiley DL \& Heiman ML. Ghrelin induces adiposity in rodents. Nature $2000 \mathbf{4 0 7} 908-913$.

9 Toshinai K, Mondal MS, Nakazato M, Date Y, Murakami N, Kojima M et al. Upregulation of ghrelin expression in the stomach upon fasting, insulin-induced hypoglycemia, and leptin administration. Biochemical and Biophysical Research Communications 2001281 1220-1225.

10 Tschöp M, Weyer C, Tataranni PA, Devanarayan V, Ravussin E \& Heiman ML. Circulating ghrelin levels are decreased in human obesity. Diabetes 200150 707-709.

11 Leclercq-Meyer V, Marchand J, Leclercq R \& Malaisse WJ. Glucagon and insulin release by the in vitro perfused rat pancreas. Diabète \& Metabolisme $1976257-65$.

12 Silvestre RA, Miralles P, Moreno P, Villanueva ML \& Marco J. Somatostatin, insulin and glucagon secretion by the perfused rat pancreas from the cysteamine-treated rat. Biochemical and Biophysical Research Communications 1986134 1291-1297.

13 Yalow RS \& Bergson SA. Immunoassay of endogenous plasma insulin in man. Journal of Clinical Investigation 196939 1157-1175.

14 Herbert V, Lau KS, Gottlieb CW \& Bleicher SJ. Coated charcoal immunoassay of insulin. Journal of Clinical Endocrinology and Metabolism 196525 1375-1384.

15 Faloona GR \& Unger RH. Glucagon. In Methods of Hormone Radioimmunoassay, pp 317-330. Eds BM Jafee \& HR Behrman. New York: New York Academic Press, 1974.

16 Harris V, Conlon JM, Srikant CB, McCorkle H, Schusdziarra V, Ipp $\mathrm{E}$ et al. Measurement of somatostatin-like immunoreactivity in plasma. Clinica Chimica Acta 197887 275-283.

17 Zawalich WS. Regulation of insulin secretion by phosphoinositide-specific phospholipase $\mathrm{C}$ and protein kinase $\mathrm{C}$ activation. Diabetes Reviews 19964 160-176.

18 Masuda Y, Tanaka T, Inomata N, Ohnuma N, Tanaka S, Itoh Z et al. Ghrelin stimulates gastric acid secretion and motility in rats. Biochemical and Biophysical Research Communications 2000 276 905-908.

19 Samols S, Weir GC \& Bonner-Weir S. Intraislet insulin-glucagonsomatostatin relationship. In Handbook of Experimental Pharmacology, vol. 2, pp 133-173. Ed. PJ Lefèbvre. Berlin: SpringerVerlag, 1983.

20 Tolle V, Zizzari P, Tomasetto C \& Rio MC. In vivo and in vitro effects of ghrelin/motilin-related peptide on growth hormone secretion in the rat. Neuroendocrinology 200173 54-61.

21 Hosoda H, Kojima M, Matsuo H \& Kangawa K. Ghrelin and desacyl ghrelin: two major forms of rat ghrelin peptide in gastrointestinal tissue. Biochemical and Biophysical Research Communications 2000279 909-913.

Received 30 July 2001

Accepted 23 October 2001 